\title{
MARK-UP AND COST DISPERSION ACROSS FIRMS: DIRECT EVIDENCE FROM PRODUCER SURVEYS IN PAKISTAN
}

\author{
David Atkin \\ Azam Chaudhry \\ Shamyla Chaudry \\ Amit K. Khandelwal \\ Eric Verhoogen \\ Working Paper 20868 \\ http://www.nber.org/papers/w20868 \\ NATIONAL BUREAU OF ECONOMIC RESEARCH \\ 1050 Massachusetts Avenue \\ Cambridge, MA 02138 \\ January 2015
}

We are grateful to Tariq Raza for excellent project management assistance, to Research Consultants (RCONS) for very ably carrying out the surveys described in the text, and to the International Growth Center (IGC) and the DfID-CEPR initiative on Private Enterprise Development in Low-Income Countries (PEDL) for funding. Yale IRB Approval \#1109009047; Columbia IRB Approval \#AAAI7550. We thank Treb Allen for comments on a preliminary draft. The views expressed herein are those of the authors and do not necessarily reflect the views of the National Bureau of Economic Research.

At least one co-author has disclosed a financial relationship of potential relevance for this research. Further information is available online at http://www.nber.org/papers/w20868.ack

NBER working papers are circulated for discussion and comment purposes. They have not been peerreviewed or been subject to the review by the NBER Board of Directors that accompanies official NBER publications.

(C) 2015 by David Atkin, Azam Chaudhry, Shamyla Chaudry, Amit K. Khandelwal, and Eric Verhoogen. All rights reserved. Short sections of text, not to exceed two paragraphs, may be quoted without explicit permission provided that full credit, including $(\mathbb{C}$ notice, is given to the source. 
Mark-up and Cost Dispersion across Firms: Direct Evidence from Producer Surveys in Pakistan David Atkin, Azam Chaudhry, Shamyla Chaudry, Amit K. Khandelwal, and Eric Verhoogen NBER Working Paper No. 20868

January 2015

JEL No. F1,L1,O25

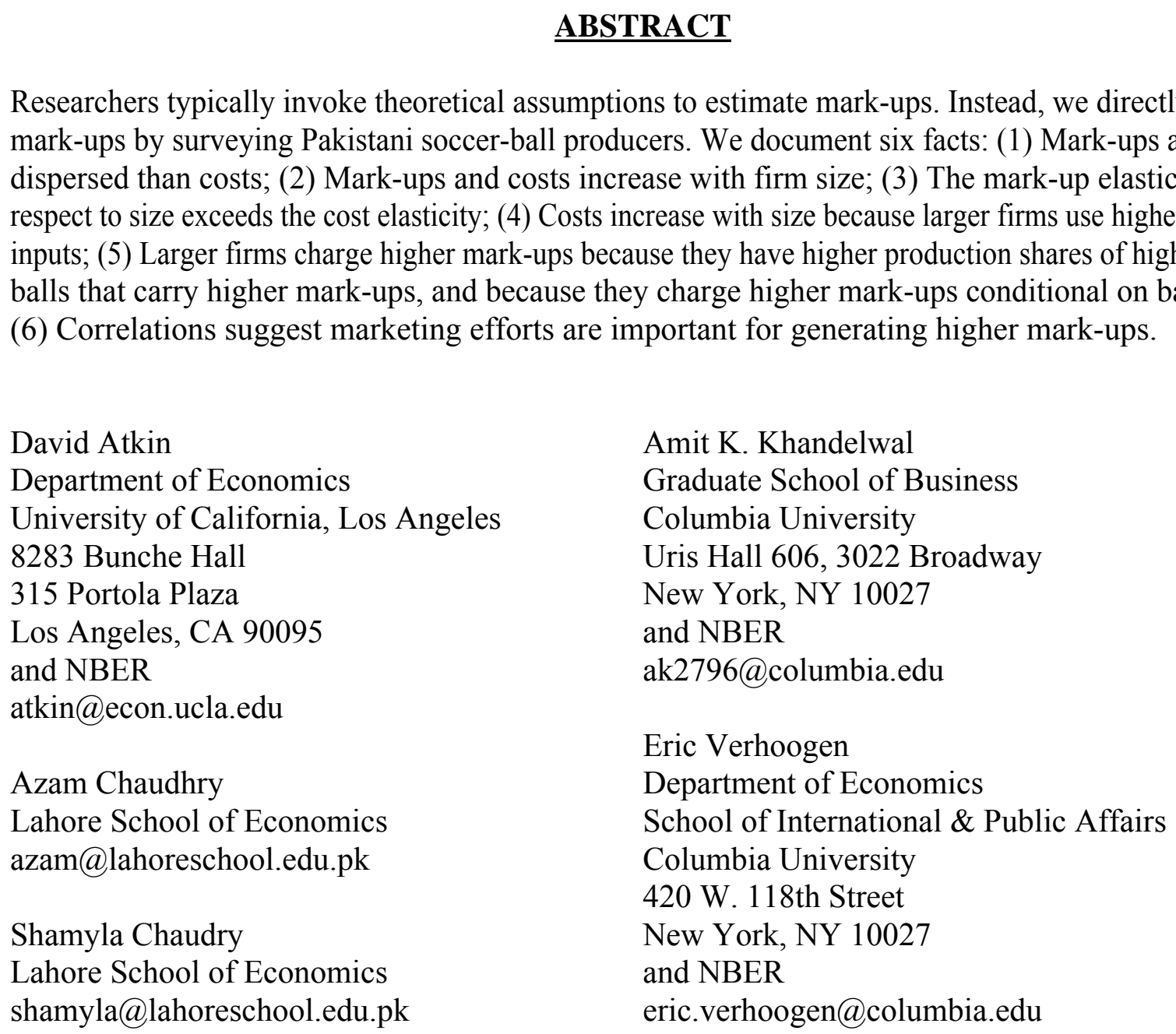




\title{
Mark-up and Cost Dispersion across Firms: Direct
}

\section{Evidence from Producer Surveys in Pakistan*}

\author{
David Atkin Azam Chaudhry Shamyla Chaudry \\ Amit K. Khandelwal Eric Verhoogen
}

January 2015

How do mark-ups differ across firms in the same narrow industry? The question is key to answering a number of bigger questions - How do firms respond to trade liberalization or industrial-policy interventions? How large are the welfare gains from trade? How do firms transmit international price shocks to local markets? How should productivity be measured? - but there is little consensus in the literature either about how to model mark-ups or about how to estimate them.

The most common theoretical approach is to assume that firms are monopolistically competitive and that representative consumers have constant-elasticity-of-substitution (CES) preferences (e.g., Melitz 2003), with the result that mark-ups are constant in multiplicative terms. Recently, there has been growing interest in more flexible approaches to modeling mark-ups. Researchers have developed tractable models with variable mark-ups by combining, for instance, CES preferences and other forms of imperfect competition (e.g., Atkeson and Burstein 2008, Edmonds, Midrigan and Xu 2011, Amiti, Itskhoki and Konings 2014), or other demand systems and monopolistic competition (e.g., Melitz and Ottaviano 2008, Zhelobodko et al. 2012). But it is not clear how to discriminate among these models based

\footnotetext{
${ }^{*}$ We are grateful to Tariq Raza for excellent project management assistance, to Research Consultants (RCONS) for very ably carrying out the surveys described in the text, and to the International Growth Center (IGC) and the DfID-CEPR initiative on Private Enterprise Development in Low-Income Countries (PEDL) for funding. Yale IRB Approval \#1109009047; Columbia IRB Approval \#AAAI7550. We thank Treb Allen for comments on a preliminary draft. Contact information: Atkin, UCLA, atkin@econ.ucla.edu; Chaudhry, Lahore School of Economics, azam@lahoreschool.edu.pk; Chaudry, Lahore School of Economics, shamyla@lahoreschool.edu.pk; Khandelwal, Columbia Graduate School of Business, ak2796@columbia.edu (corresponding author); Verhoogen, Columbia University Department of Economics and School of International and Public Affairs, eric.verhoogen@columbia.edu.
} 
on existing empirical evidence.

Empirically, there are two main approaches to estimating mark-ups. The most common is to estimate mark-ups from the "demand side", which entails specifying functional forms for consumer utility and making assumptions on the market structure of firms (e.g., Berry, Levinsohn and Pakes 1995, Goldberg 1995, Feenstra and Weinstein 2010). Alternatively, one can estimate mark-ups through the "supply side" using an approach pioneered by Hall (1986) and more recently implemented by de Loecker and Warzynski (2012) and de Loecker et al. (2012). This approach does not require functional-form assumptions about preferences or the competitive environment, and instead relies on cost minimization and two additional assumptions: that input adjustment is costless and that firms in the same industry face different, exogenously given, input prices. Studies adopting either approach find that markups do in fact vary tremendously across firms. But while each approach to estimating mark-ups has its merits, both require a measure of faith in their respective assumptions. ${ }^{1}$ Ideally, one would like to have direct measures of mark-ups that do not depend on these theoretical assumptions.

In this short paper, we take a different approach: we have directly asked firms about their mark-ups. Since 2011, we have been studying a cluster of soccer-ball manufacturers located in Sialkot, Pakistan and have learned a great deal about the ins and outs of producing soccer balls. In Atkin et al. (2014), we study the adoption of a new cost-saving technology that we invented and randomly introduced to a subset of firms. In conjunction with that study, we have directly collected information on prices and profitability, as well as the unit costs of manufacturing a standardized ball. Asking firms directly about their mark-ups is not a guarantee of accurate information. However, the facts that the producers use similar production techniques that we understand well and that we have been able to build up a modicum of trust with the firms over the course of our several-year project give us confidence that there is signal in the self-reported mark-ups. ${ }^{2}$

\footnotetext{
${ }^{1}$ See de Loecker and Goldberg (2014) for a discussion of the different approaches to estimating mark-ups.

${ }^{2}$ Our approach is in line with the recommendation of de Mel, McKenzie and Woodruff (2009) that, at
} 
As we discuss in more detail below, we have six main findings. First, dispersion in markups is greater than dispersion in costs, at least in proportional terms. Second, both costs and mark-ups are positively related to firm size, arguably the best observable proxy for the entrepreneurial-ability parameter in many heterogeneous-firm models (e.g. the "Melitz draw", $\varphi$ ). Third, the elasticity of mark-ups with respect to firm size is significantly greater than the elasticity of costs. Fourth, larger firms have greater costs primarily because they use higher-quality inputs (which are costly). Fifth, larger firms charge higher mark-ups on average both because they produce a greater share of higher-quality ball types, which carry higher mark-ups, and because they charge higher mark-ups for a given type of ball. Sixth, there is suggestive evidence that marketing efforts may play an important role is generating higher average mark-ups: mark-ups are more highly correlated with whether an entrepreneur attends an annual trade expo and sells to richer countries than with available measures of technical efficiency. In the conclusion we discuss what we consider to be the main implications of these findings for theoretical and empirical work on heterogeneous firms.

\section{Data}

Between January and April 2012 we carried out a baseline survey of the 135 soccer-ball firms located in Sialkot, Pakistan, and have since conducted eight additional survey rounds. There are four main phases of production: "lamination", which involves gluing layers of cotton or polyester to an artificial leather called rexine; cutting; printing; and stitching the cut and printed panels (usually hexagons and pentagons) around an inflatable bladder. To be considered a firm for our purposes, an establishment had to be cutting its own sheets; we excluded firms that marketed themselves as selling soccer balls but outsourced all four main phases of the production process. For details on the production process, the cluster, and our survey design, we refer the reader to Atkin et al. (2014).

In each survey round, we asked firms the price and profit per ball for each ball type they manufactured in the previous month. The two main ball types are "match/training"

least in the context of microenterprises in Sri Lanka, asking entrepreneurs directly about their profits can be more accurate than inferring profits from reported revenues and costs. 
balls, higher-quality balls that use more layers of cotton or polyester and higher-quality imported rexine, and "promotional" balls, lower-quality balls that use fewer layers of cotton or polyester and cheaper, locally produced rexine. Soccer balls come in five standard sizes, with size 5 (regulation size for adults) making up 86 percent of total production. We collected the share of production of each ball type and use it to construct average prices and mark-ups at the firm level. To reduce noise, throughout the paper we report firm-level averages across rounds. ${ }^{3}$

We define the mark-up as the level of profit per ball, such that mark-up plus cost per ball equals price. We have two ways of measuring costs. First, from the price and profit data, we infer the cost of producing each ball as price minus markup. Second, at baseline, we asked firms to give a detailed breakdown of the cost of a standard ball: a size-5, two-layer (cotton and polyester) promotional ball. ${ }^{4}$

\section{Mark-up and Cost Dispersion}

\section{A Distributions of Mark-ups and Costs}

We begin by reporting the distributions of prices, mark-ups and costs across firms. We define the average price as an average of the prices of promotionaland training balls, weighted by production shares. Average mark-ups are defined analogously. Column 1 of Table 1 reports the distribution of average prices across firms. ${ }^{5}$ The mean price is Rs 379.3 (US\$3.79 given the exchange rate of Rs 100/dollar in July 2013, approximately the midpoint of our study period). The $90-10$ ratio is 2.48 , while the $75-25$ ratio is 1.58 . Column 2 reports the distribution of average mark-ups across firms. The mean markup is Rs 31.3. This implies a

\footnotetext{
${ }^{3}$ The wording of the price question was "For each type, what is the average price per ball in rupees on the orders you have received in the past month?" and the profit question was "For each type, what is the average profit per ball in rupees on the orders you have received in the past month (e.g. your profit per ball after paying all costs)?" The set of types varied slightly across rounds; we focus on responses for two types, "Size 5 Promotional," and "Size 5 Training, Club and Match," which were elicited in each round.

${ }^{4}$ We collected eight cost components: (1) the rexine type, (2) the cotton layer; (3) the polyester layer; (4) the latex and chemical mix that binds the cotton, polyester and rexine; (5) a 60-65 gram latex bladder; (6) thread and stitching cost; (7) labor costs for lamination, sheet and cloth cutting, printing, washing, packing and matching; and (8) overhead.

${ }^{5}$ Note that while mark-up plus cost equals price for each firm, this will not hold at a given quantile across the univariate distributions, since different firms are at a given quantile for the different variables.
} 
mean profit rate of 8.26 percent, which suggests that the sector is reasonably competitive. The dispersion in mark-ups is large: the $90-10$ ratio is 5.14 while the $75-25$ ratio is 2.65 . Column 3 reports the distribution of average costs, defined as the difference between prices and mark-ups. Compared to mark-ups, the dispersion in costs is lower: the 90-10 ratio is 2.45 , while the $75-25$ ratio is 1.53 . The coefficient of variation of mark-ups is 0.73 compared to 0.45 for costs. We consider the observation that dispersion in mark-ups is greater than dispersion in costs, at least in proportional terms, to be our first main finding.

\section{Table 1: Dispersion in Mark-ups and Costs}

\begin{tabular}{lccc} 
& $\begin{array}{c}\text { Weighted Average of Promotional and Match/Training Ball (Rs) } \\
\text { Mark-up }\end{array}$ & $\begin{array}{c}\text { Cost } \\
(3)\end{array}$ \\
\hline Min & $(1)$ & 4.5 & 164.2 \\
P5 & 178.1 & 6.6 & 190.5 \\
P10 & 195.0 & 10.0 & 216.4 \\
P25 & 229.4 & 15.3 & 253.3 \\
P50 & 274.3 & 26.8 & 311.4 \\
P75 & 343.1 & 40.7 & 387.6 \\
P90 & 433.0 & 51.4 & 530.0 \\
Max & 569.3 & 160.0 & 1000.0 \\
Mean & 1160.0 & 31.3 & 348.0 \\
Std. Dev. & 379.3 & 22.8 & 154.9 \\
P90-P10 & 171.7 & 5.14 & 2.45 \\
P75-P25 & 2.48 & 2.65 & 1.53 \\
Coef. Var. & 1.58 & 0.73 & 0.45 \\
Observations & 0.45 & 93 & 93 \\
\hline \hline
\end{tabular}

Notes: Table reports measures of prices, mark-ups and costs. Columns 1-2 report a weighted average of prices and mark-ups, where the weight is the share of promotional balls in total production. Column 3 is the inferred cost that is equal to the weighted-average price minus weighted-average mark-up.

\section{B Mark-ups and Costs versus Firm Size}

To provide guidance for the theoretical modeling of mark-ups, one would like to know not just how dispersed mark-ups are, but also how mark-ups (and costs) relate to other key firm characteristics. It is common in the theoretical literature to model firms as heterogenous along a single dimension, commonly referred to as entrepreneurial ability or simply productivity. One of the most robust predictions in these models is that firms run by more able 
entrepreneurs will be larger in equilibrium. It is thus arguable that firm size is the best easily available and directly observable proxy for the entrepreneurial ability parameter. ${ }^{6}$ Motivated by these arguments, we focus on how mark-ups and costs relate to firm size.
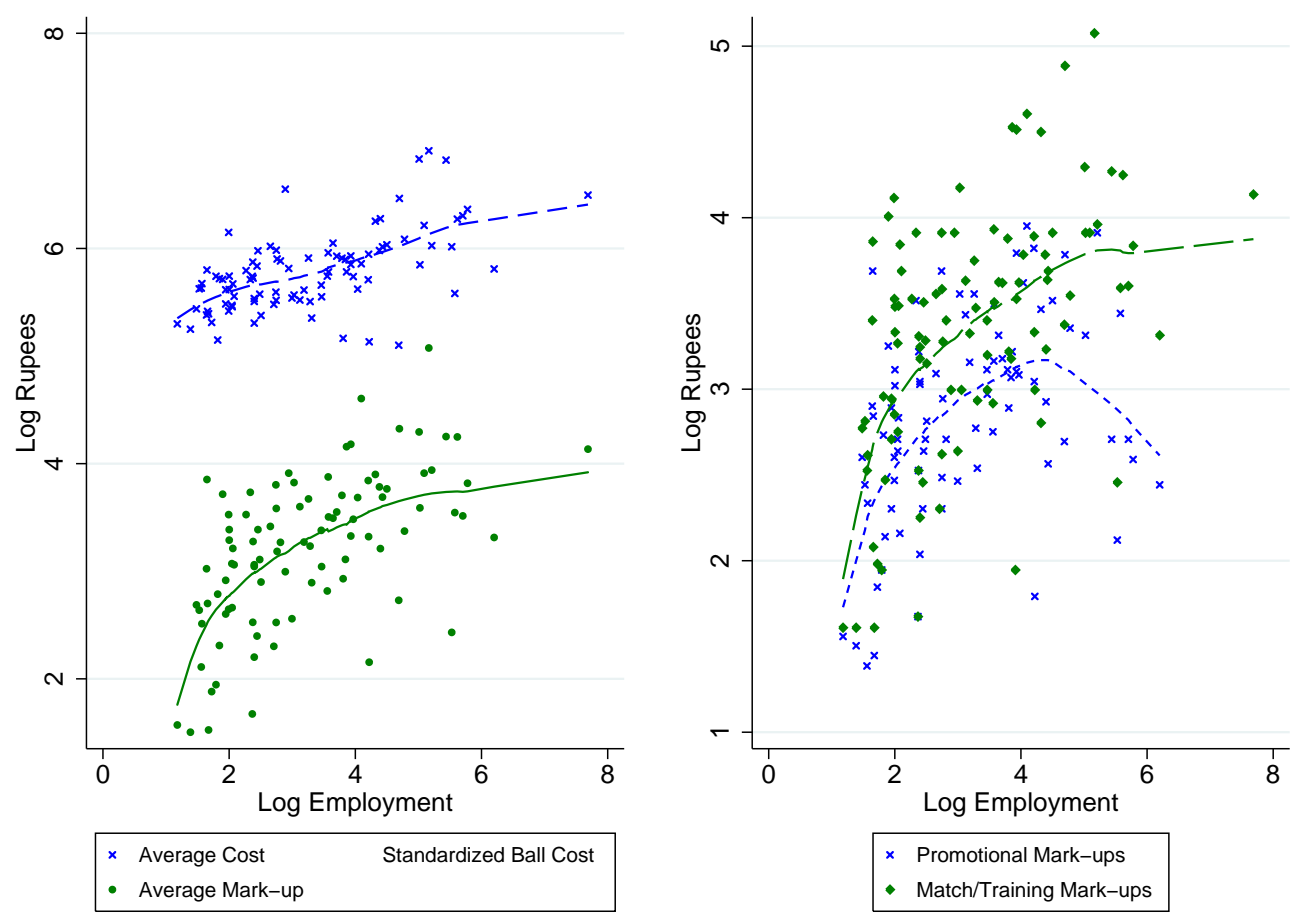

The left panel of Figure 1 plots log average mark-ups and log average costs against log firm size (as measured by employment). ${ }^{7}$ Overlaid on the raw data are non-parametric plots of log costs and log mark-ups against firm size. There are two important points to notice. First, both average costs and average mark-ups are positively correlated with firm size. Second, the elasticity of mark-ups with respect to size exceeds that for average costs. Columns 1-2 of Table 2 estimate the elasticities of the same three variables with respect to employment using linear OLS regressions. The average markup elasticity is 0.31 and the average cost elasticity is 0.16 , both highly significant and statistically different from each other. These numbers confirm the patterns observed in the left panel Figure 1. We consider

\footnotetext{
${ }^{6}$ Estimated total factor productivity is another obvious candidate, but estimating productivity requires making assumptions about the distribution of mark-ups, which seems against the spirit of our exercise of characterizing the distribution of mark-ups without relying on a particular theoretical model.

${ }^{7}$ We measure employment by taking a firm-level average of the answer to the following question: "How many total employees working inside the firm (including yourself, active partners and contract workers. Exclude stitchers that do not work inside the factory)?"
} 
the facts that mark-ups and costs are increasing in firm size, with a greater elasticity for mark-ups, to be the second and third main finding of this paper.

\section{Table 2: Mark-ups, Costs and Production Share Elasticities}

\begin{tabular}{|c|c|c|c|c|c|c|c|c|}
\hline & \multicolumn{2}{|c|}{ Weighted Averages } & \multirow{2}{*}{$\begin{array}{c}\log (\text { Std. Ball } \\
\text { Cost) } \\
\text { (3) }\end{array}$} & \multicolumn{2}{|c|}{ Promotional Ball } & \multicolumn{2}{|c|}{ Match/Training Ball } & \multirow{2}{*}{$\begin{array}{c}\text { Share of } \\
\text { Match/Training } \\
\text { (8) }\end{array}$} \\
\hline & $\begin{array}{c}\text { Log (Mark-up) } \\
(1)\end{array}$ & $\begin{array}{c}\log (\text { Cost }) \\
(2)\end{array}$ & & $\begin{array}{c}\text { Log (Mark-up) } \\
(4)\end{array}$ & $\begin{array}{c}\text { Log (Cost) } \\
(5)\end{array}$ & $\begin{array}{c}\text { Log (Mark-up) } \\
(6)\end{array}$ & $\begin{array}{c}\log (\text { Cost) } \\
(7)\end{array}$ & \\
\hline Log Employment & $\begin{array}{l}0.31 * * * \\
(0.04)\end{array}$ & $\begin{array}{l}0.16 * * * \\
(0.02)\end{array}$ & $\begin{array}{c}0.06 * \\
(0.03)\end{array}$ & $\begin{array}{l}0.19 * * * \\
(0.05)\end{array}$ & $\begin{array}{l}0.07^{* * *} \\
(0.02)\end{array}$ & $\begin{array}{l}0.28^{* * * *} \\
(0.05)\end{array}$ & $\begin{array}{l}0.15 * * * \\
(0.02)\end{array}$ & $\begin{array}{l}6.70 * * * \\
(1.84)\end{array}$ \\
\hline Constant & $\begin{array}{l}2.22 * * * \\
(0.16)\end{array}$ & $\begin{array}{l}5.25^{* * *} \\
(0.08)\end{array}$ & $\begin{array}{l}5.12 \text { *** } \\
(0.11)\end{array}$ & $\begin{array}{l}2.24^{* * *} \\
(0.16)\end{array}$ & $\begin{array}{l}5.18 * * * \\
(0.07)\end{array}$ & $\begin{array}{l}2.411^{* * *} \\
(0.17)\end{array}$ & $\begin{array}{l}5.47^{* * *} \\
(0.07)\end{array}$ & $\begin{array}{l}-58.40 * * * \\
(6.71)\end{array}$ \\
\hline R-squared & 0.34 & 0.35 & 0.09 & 0.16 & 0.11 & 0.27 & 0.34 & 0.10 \\
\hline Observations & 93 & 93 & 42 & 83 & 83 & 100 & 100 & 117 \\
\hline
\end{tabular}

Notes: Table reports the elasticities of mark-ups, costs and production shares with respect to employment. Columns 1-2 are constructed using weighted average mark-ups and costs. Column 3 uses the standardized ball cost. Columns $4-5$ are constructed using promotional balls, and columns 6 . 7 are constructed using match/training balls. Column 7 uses the share of production on match/training balls. Significance ${ }^{*} .10 ;{ }^{* *} .05 ;{ }^{* * *} .01$.

What lies behind the positive cost-size correlation? As mentioned earlier, we asked firms at baseline to report the cost of manufacturing a standardized promotional two-layer ball, allowing only for differences in rexine types. We use data on the subset of firms that were willing to break down the cost of ball into eight subcomponents to create a standardized cost that corrects for differences in the rexine type. ${ }^{8}$ Using this standardized cost measure, the elasticity with respect to size is markedly smaller than for average costs, 0.06 compared to 0.16, and only marginally significant (Table 2 Column 3); see Appendix Figure A.1 for the non-parametric plot. That is, the cost-size correlation appears to be largely explained by observable differences in the characteristics of inputs. This is consistent with the hypothesis that the differences in average input costs primarily reflect differences in input quality, which are in turn reflected in output quality (Kugler and Verhoogen, 2012). We believe that the remaining positive correlation between standardized costs and firm size is likely to be explained by unobservable characteristics of inputs, which our standardized measure was not able to control for. We consider the finding that costs increase with firm size primarily

\footnotetext{
${ }^{8}$ We regress the rexine cost per ball on a categorical variable that captures eight possible rexine types, replace a firm's rexine cost with the constant and firm-specific residual from that regression, and then sum across the eight subcomponents to compute the total (standardized) cost. We asked firms about imported rexine from Japan and Korea, two types of rexine sourced domestically from Lahore, three types of rexine produced within Sialkot, and an "other" catch-all category.
} 
because larger firms use expensive, higher-quality inputs to be our fourth main finding.

What lies behind the positive mark-up-size correlation? In the right panel of Figure 1, we look separately at how mark-ups and costs vary with firm size by ball type. Three points are salient. First, mark-ups are higher for (higher-quality) training/match balls than for (lower-quality) promotional balls: the training/match ball long-dash curve is always above the promotional ball short-dash curve. In Appendix Table A.1, we find that markups for match/training balls are 46 percent higher than promotional balls when including firm fixed effects (and the difference is statistically significant). Second, within a segment, larger firms generally have higher mark-ups, and this is particularly true for match/training balls. Columns 4-7 of Table 2 estimate the elasticities of mark-ups and costs for each ball type using OLS. The numbers indicate that 10 percent greater employment is associated with 1.9 percent and 2.8 percent higher mark-ups for promotional and match/training balls, respectively. These elasticities are higher than the cost elasticities, and this fact remains true when we consider output (physical quantity of balls) as an alternative measure of firm size in Appendix Table A.2. Third, product composition is also systematically related to firm size: larger firms produce a greater share of (higher-quality) match/training balls (Column 8 of Table 2). (Again, similar results hold in Appendix Table A.2 using total output.) In sum, average mark-ups increase with firm size because larger firms produce disproportionately more high-quality balls, and within each type of ball obtain higher mark-ups. We consider this to be our fifth main finding.

\section{Suggestive Evidence on the Role of Marketing}

What is it about larger firms that allows them to generate orders for higher-quality balls and sign contracts that provide higher mark-ups? Our discussions with firms suggest that customer-building and marketing activities are important. In order to shed further light on this possibility, Table 3 reports pair-wise correlations between four variables in our dataset that proxy for either marketing intensity or productivity and the four outcome metrics studied above. (The pair-wise correlations among the four outcome metrics are reported in 
Appendix Table A.3.) We find that average mark-ups are positively correlated with both the share of output sold to high-income countries and with an indicator for whether the firm attended the major international sports goods trade fair (called ISPO) in Germany in 2012. The correlation between mark-ups and two productivity measures, the self-reported average number of balls cut from a single rexine sheet and total output per employee, is far weaker. ${ }^{9}$ Columns 2 and 3 report correlations with average costs and standardized ball costs. Average costs are positively correlated with the share of balls sold to high-income countries and attending ISPO, consistent with the hypothesis that rich-country customers demand more higher-quality balls that require expensive inputs. Consistent with this explanation, the correlation falls to zero or becomes small and negative for the standardized ball cost that largely controls for input costs. The correlations with the two productivity measures are negative as expected, but again small in magnitude. Column 4 reports the correlations with firm size. We see that the two marketing proxies correlate much more strongly with employment than the two productivity measures (although the negative correlation with output per employee is somewhat mechanical).

Table 3: Mark-ups, Costs and Employment Correlations

\begin{tabular}{lcccc} 
& & \multicolumn{2}{c}{ Standardized Ball } \\
& Average Mark-up & Average Cost & Cost & \multicolumn{2}{c}{ Employment } \\
& $(1)$ & $(2)$ & $(3)$ & $(4)$ \\
\hline Share of balls to high-income destination & 0.20 & 0.22 & 0.01 & 0.13 \\
Attend ISPO? & 0.48 & 0.44 & -0.08 & 0.11 \\
(Self-reported) Balls per sheet & 0.02 & -0.11 & -0.08 & -0.05 \\
Output per employee & 0.02 & -0.15 & -0.11 & -0.19 \\
\hline \hline
\end{tabular}

Notes: Table reports pairwise correlations between the outcomes variables and the proxies for marketing and technical efficiency described in the text.

Caution is warranted in interpreting these correlations. It may be that marketing skill is part of what is typically thought of as entrepreneurial ability, or the firms that attend

\footnotetext{
${ }^{9}$ In addition, if technical efficiency varied significantly with firm size, we might have expected the correlation between standardized ball cost and firm size to be negative in Table 2, Column 3 and Appendix Figure A.1. While unobservable input-quality differences could be more than offsetting any differences in technical efficiency by size, in our view the more plausible explanation, consistent with the evidence from Table 3, is simply that technical efficiency varies relatively little with firm size.
} 
the ISPO and sell more to rich countries may be ones that have benefited from fortuitous demand shocks from rich-country customers in the past. In addition, although we did not find much of a gradient in standardized ball costs for a simple, relatively low-quality ball, it may be that entrepreneurial ability matters more for high-quality balls, for which we did not collect a standardized cost measure. In short, there may be complicated interactions between marketing skill, demand shocks, and high-quality-specific know-how. But the correlations reported in Table 3 do suggest that mark-ups are not a simple function of quality-neutral technical efficiency, and are sufficiently worthy of further investigation that we consider them to be our sixth main finding.

\section{Conclusion}

In this paper, we have documented a number of facts about how mark-ups and costs differ across soccer-ball producers in Sialkot, Pakistan. Although focused on a specific setting, our findings have the advantage that they are based on direct measures of mark-ups and do not require the strong assumptions of common structural approaches.

What are the implications of our findings for the heterogeneous-firms literature? In

relation to the existing literature on variable mark-ups, perhaps our most important finding is that mark-ups systematically increase in firm size. The positive elasticity of mark-ups to firm size is greater than that of costs, and holds not only on average but also within narrowly defined product types. It will be important to investigate whether this pattern holds in other settings. But assuming that the pattern proves to be general, it suggests that the theoretical literature should focus on models that can rationalize a positive relationship between mark-ups and entrepreneurial ability.

The results that average costs are positively correlated with firm size, that the correlation is significantly reduced by controlling for input quality (as in our standardized cost measure), and that larger firms produce a greater share of higher-quality ball types are in line with the existing literature on quality and heterogeneous firms (Kugler and Verhoogen, 2012). But 
the quality literature has had relatively little to say about mark-ups, and this paper suggests variation in mark-ups is a first-order feature of the data.

We believe that our findings point to several potentially fruitful directions for future work. A natural question to ask is why mark-ups differ so significantly across firms. We have presented suggestive evidence that marketing and customer-building activities may play an important role. This evidence is consistent with a set of case studies by Artopoulos, Friel and Hallak (2013), who found that a distinguishing feature of export pioneers in Argentina was their knowledge of (and "embeddedness" in) foreign markets, rather than purely technical expertise. Another topic that seems promising is the link between product quality and mark-ups; our evidence confirms that higher-quality ball types carry systematically higher mark-ups. While the idea that there is a systematic relationship between quality and markups has been "in the air" for many years (and has been formalized for instance in Manova and Zhang (2012)), the reasons for the relationship remain poorly understood.

\section{References}

Amiti, Mary, Oleg Itskhoki, and Jozef Konings. 2014. "Importers, Exporters, and Exchange Rate Disconnect." American Economic Review, 104(7): 1942-1978.

Artopoulos, Alejandro, Daniel Friel, and Juan Carlos Hallak. 2013. "Export emergence of differentiated goods from developing countries: Export pioneers and business practices in Argentina." Journal of Development Economics, 105(C): 19-35.

Atkeson, Andrew, and Ariel Burstein. 2008. "Pricing-to-Market, Trade Costs, and International Relative Prices." American Economic Review, 98(5): 1998-2031.

Atkin, David, Azam Chaudhry, Shamyla Chaudry, Amit Khandelwal, and Eric Verhoogen. 2014. "Organizational Barriers to Technology Adoption: Evidence from Soccer-ball Producers in Pakistan." Mimeo, Columbia University.

Berry, Steven, James Levinsohn, and Ariel Pakes. 1995. "Automobile Prices in Market Equilibrium." Econometrica, 63(4): 841-90.

de Loecker, Jan, and Frederic Warzynski. 2012. "Markups and Firm-level Export Status." American Economic Review, 102(6): 2437-2471. 
de Loecker, Jan, and Pinelopi Goldberg. 2014. "Firm Performance in a Global Market." Annual Review of Economics, 6(1): 201-227.

de Loecker, Jan, Pinelopi Goldberg, Amit Khandelwal, and Nina Pavcnik. 2012. "Prices, Markups and Trade Reforms." NBER Working Paper 17925.

de Mel, Suresh, David McKenzie, and Christopher Woodruff. 2009. "Measuring microenterprise profits: Must we ask how the sausage is made?" Journal of Development Economics, 88(1): 19-31.

Edmonds, Chris, Virgiliu Midrigan, and Yi Xu. 2011. "Competition, Markups and the Gains from International Trade." Mimeo, Duke University.

Feenstra, Robert C., and David Weinstein. 2010. "Globalization, Markups, and the U.S. Price Level." NBER Working Paper 15749.

Goldberg, Pinelopi Koujianou. 1995. "Product Differentiation and Oligopoly in International Markets: The Case of the U.S. Automobile Industry." Econometrica, 63(4): 891-951.

Hall, Robert E. 1986. "Market Structure and Macroeconomic Fluctuations." Brookings Papers on Economic Activity, 17(2): 285-338.

Kugler, Maurice, and Eric Verhoogen. 2012. "Prices, Plant Size, and Product Quality." The Review of Economic Studies, 79: 307-339.

Manova, Kalina, and Zhiwei Zhang. 2012. "Export Prices Across Firms and Destinations." The Quarterly Journal of Economics, 127(1): 379-436.

Melitz, Marc J. 2003. "The Impact of Trade on Intra-Industry Reallocations and Aggregate Industry Productivity." Econometrica, 71(6): 1695-1725.

Melitz, Marc J., and Giancarlo I. P. Ottaviano. 2008. "Market Size, Trade, and Productivity." Review of Economic Studies, 75(1): 295-316.

Zhelobodko, Evgeny, Sergey Kokovin, Mathieu Parenti, and Jacques-Francois Thisse. 2012. "Monopolistic Competition: Beyond the Constant Elasticity of Substitution." Econometrica, 80(6): 2765-2784. 


\section{Appendix}

Table A.1: Mark-ups and Quality

Log Mark-up Log Mark-up

(1)

(2)

\begin{tabular}{lcc}
\hline Indicator for Match/Training Ball & $0.54 * * *$ & $0.46 * * *$ \\
& $(0.10)$ & $(0.05)$ \\
Constant & $2.77^{* * *}$ & $2.81 * * *$ \\
& $(0.07)$ & $(0.04)$ \\
\hline Firm Fixed Effects? & 0.14 & yos \\
R-squared & 206 & 0.88 \\
Observations & 206 \\
\hline \hline Notes: Table reports regressions of (log) mark-ups on an indicator if \\
the ball type is a match/training ball. The second column includes \\
firm fixed effects. Significance * .10; **.05; ***.01.
\end{tabular}

Table A.2: Mark-up, Costs and Production Share Elasticities: Output

\begin{tabular}{|c|c|c|c|c|c|c|c|c|}
\hline & \multicolumn{2}{|c|}{ Weighted Averages } & \multirow{2}{*}{$\begin{array}{c}\log \text { (Std. Ball } \\
\text { Cost) } \\
\text { (3) }\end{array}$} & \multicolumn{2}{|c|}{ Promotional Ball } & \multicolumn{2}{|c|}{ Match/Training Ball } & \multirow{2}{*}{$\begin{array}{c}\text { Share of } \\
\text { Match/Training } \\
\text { (8) }\end{array}$} \\
\hline & $\begin{array}{c}\log \text { (Mark-up) } \\
\text { (1) }\end{array}$ & $\begin{array}{c}\log (\text { Cost) } \\
(2)\end{array}$ & & $\begin{array}{c}\text { Log (Mark-up) } \\
\text { (4) }\end{array}$ & $\begin{array}{c}\text { Log (Cost) } \\
(5) \\
\end{array}$ & $\begin{array}{c}\log \text { (Mark-up) } \\
(6) \\
\end{array}$ & $\begin{array}{c}\log (\text { Cost) } \\
(7) \\
\end{array}$ & \\
\hline Log Output & $\begin{array}{l}0.25^{* * *} \\
(0.05)\end{array}$ & $\begin{array}{l}0.11^{* * *} \\
(0.03)\end{array}$ & $\begin{array}{r}0.03 \\
(0.03)\end{array}$ & $\begin{array}{l}0.18^{* * *} \\
(0.04)\end{array}$ & $\begin{array}{r}0.03 \\
(0.02)\end{array}$ & $\begin{array}{l}0.22 \text { *** } \\
(0.05)\end{array}$ & $\begin{array}{l}0.122^{* * *} \\
(0.02)\end{array}$ & $\begin{array}{l}6.08^{* * *} \\
(1.83)\end{array}$ \\
\hline Constant & $\begin{array}{c}0.78 * \\
(0.44)\end{array}$ & $\begin{array}{l}4.73^{* * *} \\
(0.24)\end{array}$ & $\begin{array}{l}5.03 * * * \\
(0.27)\end{array}$ & $\begin{array}{l}1.15^{* * *} \\
(0.41)\end{array}$ & $\begin{array}{l}5.15^{* * *} \\
(0.19)\end{array}$ & $\begin{array}{l}1.19^{* *} \\
(0.46)\end{array}$ & $\begin{array}{l}4.85^{* * * *} \\
(0.21)\end{array}$ & $\begin{array}{l}-93.80 * * * \\
(17.68)\end{array}$ \\
\hline R-squared & 0.25 & 0.17 & 0.03 & 0.18 & 0.02 & 0.19 & 0.23 & 0.09 \\
\hline Observations & 93 & 93 & 42 & 83 & 83 & 100 & 100 & 117 \\
\hline
\end{tabular}

Notes: Table reports the elasticities of mark-ups, costs and production shares with respect to output. Columns 1-2 are constructed using weighted average mark-ups and costs. Column 3 uses the standardized ball cost. Columns 4-5 are constructed using promotional balls, and columns 6-7 are constructed using match/training balls. Column 7 uses the share of production on match/training balls. Significance ${ }^{*} .10 ; * * .05 ;{ }^{* * *} .01$.

Table A.3: Correlation Matrix between Mark-ups, Costs, Standardized Ball Costs, and Employment

\begin{tabular}{lcccc} 
& & \multicolumn{2}{c}{ Standardized Ball } \\
& Average Mark-up & Average Cost & Cost & \multicolumn{2}{c}{ Employment } \\
& $(1)$ & $(2)$ & $(3)$ & - \\
\hline Average Mark-up & 1 & - & - & - \\
Average Cost & 0.54 & 1 & 1 & - \\
Standardized Ball Cost & -0.03 & 0.23 & 0.09 & 1 \\
Employment & 0.30 & 0.52 & $4)$ \\
\hline \hline
\end{tabular}

Notes: The table reports the correlation matrix between the four main outcomes discussed in the text. 
Figure A.1: Standardized Ball Cost versus Firm Size

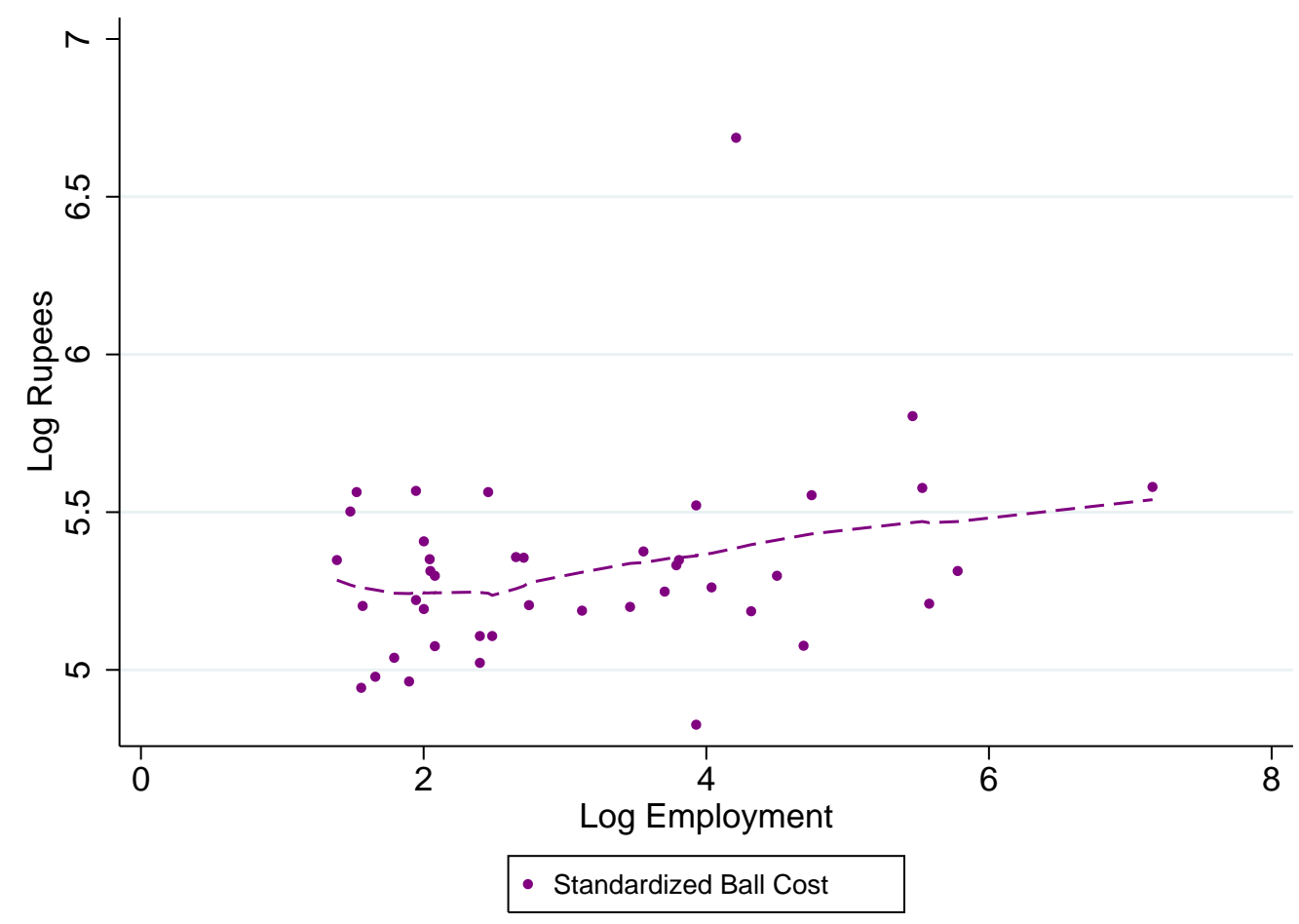

